\title{
Narince üzüm çeşidinde salamuralık yaprak toplamanın yıllık dal kalitesi ve göz verimliliğine etkisi*
}

\author{
Ali ÖZGÜR ${ }^{\circledR 1}$, Rüstem CANGi $\left(D 2\right.$, Tuba UZUN ${ }^{\circledR} 3$ \\ ${ }^{1}$ Tarım ve Orman Bakanlığı, Akören İlçe tarım Müdürlüğü, Konya \\ ${ }^{2}$ Tokat Gaziosmanpaşa Üniversitesi, Ziraat Fakültesi, Bahçe Bitkileri Bölümü, Tokat \\ ${ }^{3}$ Siirt Üniversitesi, Ziraat Fakültesi, Bahçe Bitkileri Bölümü, Siirt \\ *Bu çalıșma Yüksek Lisans tezinden alıntılanarak hazırlanmıștır.
}

Alınış tarihi: 12 Şubat 2020, Kabul tarihi: 4 Ocak 2021

Sorumlu yazar: Rüstem CANGİ, e-posta: rustem.cangi@gop.edu.tr

\section{Öz}

Amaç: Tokat ilinde Narince üzüm çeşidinin hem yaprağı hem de üzümü ticari olarak değerlendirilmektedir. 2015 ve 2016 ylllarında gerçekleștirilen bu çalıșmada, Narince üzüm çeșidinde salamuralık yaprak toplama miktarının, yıllık dal gelişimi ve kış gözlerinin verimliliğine etkisini belirlemek amaçlanmıştır.

Materyal ve Yöntem: İlk yıl asmalardan dört farklı $(0,2,4$ ve 6 dönem) seviyede yaprak toplanmıștır. İkinci yıl, dormant dönemde bir yaşlı dallarda çelik ağırlı̆̆ı, çelik uzunluğu, çelik çapı, kuru madde oranları, göz verimlilik ve düşük sıcaklığa tolerans verileri saptanmıștır. Uygulama yapılan asmalardan alınan çeliklerde ilk 10'ar boğumdaki gözlerin pozisyonlarına göre verimlilikleri kaynaștırma ünitesinde sürdürme yöntemiyle belirlenmiștir.

Araştırma Bulguları: Kontrol ve altı dönem yaprak toplama uygulamaları, göz verimliliği ve sürgün kuru madde oranını olumsuz yönde etkilemiștir. En fazla salkım sayısı 5. ve 6. (sirasıyla 1.375 ve 1.475 adet/boğum) boğumlarda saptanmıştır. İki ve dört dönem yaprak toplama, göz verimliliğini olumlu yönde etkilemiştir. On boğumlu çeliklerde ortalama çelik ağırlığı, çelik uzunluğu ve çelik çapı sırasıyla; 64.12-44.15 g; 74.89 -64.00 cm; 8.81-7.71 mm olarak belirlenmiștir. Kıșllk gözlerde ortalama salkım sayısı 1.215 adet (2 hasat) ile 0.97 adet ( 6 hasat) arasında değişmiştir.

Sonuç: Sonuç olarak, yaprak toplanan bağlarda sürgün gelişimi ve göz verimliliği açısından en fazla 4 dönem yaprak toplanması önerilmiştir.
Anahtar kelimeler: Vitis vinifera L., çelik çapı, göz sürdürme, kuru madde oranı, kış gözü

Effects of brined vine leaf picking on cane quality and bud fertility at Narince grape cultivar

\begin{abstract}
Objective: Narince grapes cultivar's both leaf and grape are commercially evaluated in Tokat region. This study was conducted in 2015 and 2016, It is aimed to determine the effects of picking frequency of brine vine leaf in Narince cultivar on cane development and winter bud fertility were aimed to be determined.
\end{abstract}

Materials and Methods: In the first year, vine leaves were collected at four different levels $(0,2,4$ and 6 periods). In the second year, cutting weights, cutting diameters, cutting length, dry matter rates, bud fertility and low-temperature tolerance datas were determined in vine cane. In treated grapevines, bud fertility was examined based on 10 nodes for their positions by shooting method in the stratification room.

Results: The control and six times leaf picking practices affected bud fertility and dry matter rate negatively. The highest number of clusters was detected in the 5th and 6th 1.375 and 1.475 clones / node) nodes. Two and four times leaf picking practices have affected positively bud fertility. It was determined the average cutting weight, cutting length and cutting diameter in 10-noded cuttings; $64.12 \mathrm{~g}-44.15 \mathrm{~g} ; 74.89 \mathrm{~cm}-64.00 \mathrm{~cm} ; 8.81 \mathrm{~mm}-7.71$ $\mathrm{mm}$, respectively. The average number of clusters in 
buds ranged from 1.215 (2 times leaf pickings) to 0.97 ( 6 time leaf pickings).

Conclusion: As a result, In terms of shoot development and bud fertility, it has been suggested leaf picking at maximum 4 times in leaf collected vineyards.

Key words: Vitis vinifera L., cutting diameter, bud shooting, dry matter rate, dormant bud

\section{Giriş}

Asmalarda budama; gelişmeyi doğrudan etkileyen ve asmanın çubuk, sürgün, salkım, yaprak gibi kısımlarının kesilmesi veya koparılması ișlemidir. Budamada bir yıllık dallar üzerinde bulunan kışlık gözler verimi belirleyen önemli unsurlardan biridir. Bir yaşlı sürgün üzerinde yer alan kış gözleri, içinde salkım ve yaprak taslaklarını beraber bulundurdukları için karışık göz tipindedirler (Fidan, 1966). Kültür asmasının (Vitis vinifera L.) kış gözlerinde 3 adet sürgün yatağı (tomurcuk) bulunmakta olup, Mayıs ayından itibaren kış gözlerinin içinde oluşmaya başlayan salkım taslaklarının miktarı, vejetasyon periyodunun sonunda kesin olarak belirginleşmektedir (Alleweldt, 1964; Ağaoğlu, 1973).

Bağcılıkta üzüm verimi bakımından en önemli tomurcuk, kış gözünün orta sürgün yatağında bulunan primer tomurcuktur (Oraman, 1959). Asmada verimlilik ölçüsü, dış görünüş olarak üzüm salkımlarının ve tanelerin sayısı ve büyüklügü ile karakterize edilebilmekle birlikte, belirtilen bu özellikler çeşit, anaç, kültürel uygulamalar ve çeşitli çevresel etmenleri içeren çok karışık olayların neticesinde oluşmaktadır (Ağaoğlu, 2002).

Primer tomurcuklardaki salkım sayısı genellikle 1-4 arasında olup, bu sayı üzüm çeşitlerine göre değişmektedir (Ağaoğlu, 1999). Salkım taslağı oluşumunun, kış gözünün bir yıllık dal üzerindeki seviyesine, asmanın yaşına, beslenme durumuna ve çeşit özelliğine bağlı olarak değişebileceği belirtilmektedir (Alleweldt ve İlter 1969; Ağaoğlu, 1973; İlter, 1980).

Yeşil budama uygulamalarından uç alma ve yaprak seyreltmenin asma gözleri içerisindeki generatif oluşum üzerine az ya da çok teşvik edici veya ket vurucu etkileri olabilmektedir (Coombe, 1959; Currle ve ark., 1983). Bu uygulamalar primer tomurcuk içerisinde salkım taslağı farklılaşması dönemlerinde yapılacak olursa, özellikle asmanın diğer organları ile salkım taslağı arasında bir rekabete sebebiyet vererek, yetiştirme tekniği veya çeşide bağlı olarak farklı sonuçlar doğurabilmektedir (Ağaoğlu, 2002).

Bağlarda yaz budaması kapsamında yer alan yaprak alma, zamanında ve yeterli düzeyde yapıldığında omca üzerinde herhangi bir olumsuz etkisi olmadığı gibi, renkli üzüm çeşitlerinde tanelerin daha iyi renklenmesi ve özellikle yağıșlı bölgelerde daha iyi bir havalanma sağlayarak, hastalıkları da bir ölçüde engellemesi gibi olumlu etkileri de söz konusudur (Winkler ve ark., 1974). Özellikle Manisa ve Tokat gibi yöre bağlarında yaprak toplama uygulamaları, yaprağın üzüm gibi ticari bir ürün olarak değerlendirilmesi amacıyla yapılmaktadır. Yemeklik asma yaprak üretiminin önemli bölgelerinden biri olan Tokat ilinde, Narince üzüm çeşidinde yapraklar mayıs ayının sonu ile temmuz ayının son haftasına kadar süren 35-70 günlük periyotta toplanmaktadır. Tokat yöresinde üreticilerin dekardan topladıkları yaprak miktarı araştırmalarda değişik miktarlarda bildirmiş olup, Cangi ve ark. (2005), 333.75 kg, Elmalı (2008), 400 kg Bekar ve Cangi (2015), 800 kg olduğunu rapor etmişlerdir.

Ilıman iklim kuşağındaki ülkelerde söz konusu tomurcukların farklılaşma olayı çeşit ve ekolojiye bağlı olmakla birlikte, mayıs başı ile haziran başı arasında sürgünlerin $25-40 \mathrm{~cm}$ olduğu dönemde meydana gelmektedir. Kuzey iklim bölgelerine çıkıldıkça Temmuz başına kayan farklılaşma, Güneye inildikçe Nisan sonunda gerçekleşmektedir (Fidan, 1966; Ağaoğlu, 1969). Yaprak hasadı ve gözlerde tomurcukların farklılaşmasının aynı döneme denk geldiği anlaşılmaktadır.

Ülkemizin salamuralı yaprak talebinin önemli bir kısmını Tokat yöresinin en önemli yemeklik yaprak kalitesi yüksek olan Narince çeşidi karşılamaktadır. Tokat bölgesinde bu çeşidin meyveleri ise sofralık, şaraplık ve şıralık olarak değerlendirilmektedir. Bu çeşidin göz verimliliği konusunda araştırma yapan Kara ve Ağaoğlu (1992), 12 Farklı Amerikan asma anacına aşılı Narince üzüm çeşidinde boğumların pozisyonları ve çaplarına göre verim potansiyelini omca üzerinde sürdürme yöntemi ile incelemişlerdir. Maksimum salkım sayısı 1.5-2.0 adet arasında değişirken bu sayıya sahip boğum numaraları da anaçlara göre değişiklik göstermiştir. Ağaoğlu ve Kara (1993), Tokat yöresinde yetiştirilen 37 üzüm çeşidinde gözlerin pozisyonlarına göre verimliliklerini serada sürdürme yöntemiyle incelemişlerdir. Narince çeșidinde 1-10. Boğumlar arasında saptanan salkım sayısını ayrıca saptamışlardır. 
Asmalarda yaprak alma, çiçeklenme öncesi-ben düşme arasındaki dönemde yapılabilmekte ve farklı sonuçlara yol açmaktadır. Ben düşme döneminde bazal yaprakların fotosentetik aktivitesi, orta ve apikal kısımdaki yapraklardan daha düşüktür. $\mathrm{Bu}$ dönemde yaprak alma, ışık ve sıcaklığa maruz kalma açısından güçlü bir etkiye sahip olsa da, fotosentetik ürün üretim/tüketim dengesi üzerinde etkisi sınırlıdır. Çiçeklenme öncesi bazal yaprakların kaldırılması durumunda ise, verimin azalması, çoğu çeşitte tane kalitesinin artması ile ilișkili olarak üretim/tüketim dengesinde etkili olmaktadır (Poni ve ark., 2006; Intrieri ve ark., 2008). Bu tepkiler, çiçeklenme ve tane tutum dönemi arasındaki periyotta sürgünler üzerindeki üretici yaprak sayısı ile sıkı bir ilișkinin yansımasıdır (Coombe, 1962).

Yaprak alma uygulamaları, bağcılığın en çok araștırılan konulardan birisidir. $\mathrm{Bu}$ araștırmalar asma fizyolojisi üzerinde ayrıntılı bilgi edinme yanında verim ve kaliteyi doğrudan etkilemesi nedeni ile yetiştiricilik yönünden de yoğunluk kazanmıştır. Yaprak alma çalışmalarının çoğunluğu çiçeklenme ile hasat arasındaki dönemde yapılmıştır. Yaprak alma uygulamalarının etkileri değișik yönlerde incelenmiştir. Alınan sonuçlar çeşide, uygulama şekli ve zamanına bağlı olarak farklılık göstermektedir. Bununla birlikte sert yaprak alma uygulamalarının verim ve gelişmeyi olumsuz yönde etkilediğini bildiren literatür bildirișleri çoğunluktadır (May ve ark., 1969; Kliewer ve Ough, 1970; Kliewer ve Fuller, 1973).

Bekar ve Cangi (2015), salamuralık yaprak hasadının verim ve meyve kalitesine olan etkilerini araştırmışlardır. Narince üzüm çeşidine ait asmalarda kontrol ve 6 dönem yaprak toplama uygulamasının verim, salkım ve tane özelliklerine etkileri incelenmiştir. 6 dönem yaprak hasadı ile dekardan 826-815 kg yaprak (200 000 adet $)$ toplanmıştır. Yaprak toplanan asmalarda kontrole göre verim, salkım ağırlı̆̆ı, tane iriliği düşmüștür. Bölge üreticilerine üzüm veya sadece yaprak üretimine yönelik modelin uygulanması önerilmiştir.

Beslic ve ark. (2013), Cabernet Sauvignon ve Prokupac çeşitlerinde bazal kısımda yaprak almanın, verimi, salkımda tane sayısı ve tane iriliğini düşürdügüu, şırada kuru maddeyi artırdığını bildirmişlerdir.

Yoğun sürgün gelişiminin olduğu erken dönemde yaprak alma, fotosentetik aktivite yüzeyinin azaltılması yüzünden, toplam sürgün fotosentez seviyesinin $\% 70$ üzerinde azalmasına neden olabilmektedir. Fotosentetik şok tüketim yapan organların gelişmesinin durmasına neden olmaktadır. $\mathrm{Bu}$, verimin düşmesi, salkımda tane sayısında azalma, daha küçük tane iriliği ve kabuk/pulp oranının değişmesi şeklinde gerçekleşmektedir. Üzümün yapısındaki değişiklikler, şırada kuru madde ve tane kabuğundaki fenolik madde içeriklerinin birikiminin artışı ile alakalıdır. Üzüm ve tanede en belirgin değişiklikler, tanede hücre bölünmesinin yoğun olduğu (çiçeklenme sonrasında) safhada yaprak toplandığı zaman, daha küçük ve seyrek salkımlar, daha düşük verime neden olmaktadır (Intrieri ve ark., 2008).

Narince üzüm çeşidinde üç ve beş dönem salamuralık yaprak ve farklı dönemlerde hasadını içeren 6 farklı üretim modeli araştırılmıştır. Salamuralık asma yaprağı verimi $126.8 \mathrm{~kg} \mathrm{da}^{-1}$ (üç dönem) ile $199.6 \mathrm{~kg} \mathrm{da}^{-1}$ (beş dönem) arasında değiştiği bildirilmiştir. Salamuralık yaprak toplanan asmalarda üzüm veriminin azaldığı, en yüksek üzüm veriminin $2561.7 \mathrm{~kg} \mathrm{da}^{-1}$ ile kontrol uygulamasında olduğu saptamışlardır. Sonuç olarak, üç dönem salamuralık yaprak + olgun üzüm yetiştiriciliğinin en karlı üretim modeli olduğu tespit edilmiștir (Cangi ve Yağcl, 2012).

Asmalardan yemeklik amaçla yaprak toplama uygulamalarının, göz verimliliği ve vejetatif gelişmeye etkisi üzerinde bugüne kadar çalışma yapılmamıştır. $\mathrm{Bu}$ araştırmada, Narince üzüm çeşidinde salamuralık yaprak toplamanın, yıllık dal gelişimi ve göz verimliliğine etkilerini belirlemek amaçlanmıştır.

\section{Materyal ve Yöntem \\ Materyal}

Araştırma 2015 ve 2016 yıllarında Tokat ili Merkez ilçeye bağlı Çarıksız Köyü'nde üretici bağında gerçekleştirilmiştir. Deneme bağ 9.5 da olup, 1989 yılında tesis edilmiştir. Asmalar 1103P anacı üzerine aşılı Narince çeşidine ait olup, dikim sıklığ SAxSÜ=3x1.75 m'dir. Asmalar çift kollu telli terbiye sistemine sahip, kısa budama yapılmaktadır. Kolların yerden yüksekliği 25-40 cm'dir. 677 m rakıma sahip bağın, koordinatları enlem $40^{\circ} 19^{\prime} 59^{\prime \prime} K$ ve boylam $36^{\circ} 15^{\prime} 48^{\prime \prime} D^{\prime}$ da bulunmaktadır.

\section{Yöntem}

Araştırmanın asmalardan yaprak toplama aşaması 2015 yılında vejetasyon döneminde gerçekleştirilmiştir. Yaprak toplama uygulamalarının bir yaşlı dalların bazı özellikleri ve kışlık gözlerde 
verimlilik düzeyleri ile ilgili aşamaları ise 2016 yılında gerçekleștirilmiştir.

\section{Denemenin Planlanması ve Salamuralık Yaprak Toplama Aşaması (2015)}

2015 yılı Şubat ayında öncelikle bağda denemenin gerçekleştirileceği asmalar seçilmiştir. Bağda sağlıklı ve homojen gelişme gösteren asmalar işaretlendikten sonra, eșit șekilde göz kalacak şekilde kıș budamasına tabi tutulmușlardır $(20 \pm 2$ göz/omca). Bağda yazın ek sulama yapılmamıștır. Bağda temel gübreleme toprak analiz sonuçlarına göre yapılmıştır. Araştırmada asmalarda 4 farklı yaprak hasat uygulaması yer almıștır.

Yaprakların toplandıkları tarihler; 30 Mayıs, 6-1317-27-30 Haziran 2015' dir. Denemede çiçeklenme öncesi ile ben düşme dönemi arasında olgun yaprağın $2 / 3$ büyüklüğüne erişen tüm yapraklar toplanmıștır. Sürgünlerin bazal kısmında dört yaprak daimi olarak bırakılmıştır (Kılıç, 2007). Kontrol asmalarında yaprak toplanmamıștır.

\section{Bir yaşlı çeliklerin gelişim ve göz verimliliği ile} ilgili işlemler(2016)

Uygulama yapılan asmalardan 6-11 Mart 2016 tarihlerinde 2 aşamada sürgünler alınmıştır. İlk aşamada 6 Mart 2016 tarihinde omçalardan kesilen bir yaşlı dallarda ölçüm, tartım değerleri saptanmıştır. Bu dönemde alınan çeliklerde göz verimlilikleri için kalemlerin sürdürme kasalarına dikimleri de yapılmıştır.

\section{Bir yaşlı çeliklerde alınan veriler}

Yaprak hasadının yıllık dalın bazı özellikleri üzerine etkisini saptamak için, 6 Mart 2016 tarihinde 11-12 göz içeren bir yaşlı çelikler asmalardan kesilerek, nemini kaybetmeyecek şekilde aseptik torbalara koyularak laboratuvara getirilmiştir.

Yıllık dalların ağırlıkları, çapları ve uzunlukları her uygulamadan alınan 30 adet bir yaşlı çelikte saptanmıştır.

Bir yaşlı çelik ağırlıkları (g/adet); Bir yaşlı çeliklerin $0.01 \mathrm{~g}$ hassasiyetli dijital terazide tek tek tartılmasıyla saptanmıştır.

Bir yaşlı çelik çapı (mm); Bir yaşlı çeliklerde 3 farklı noktada ventral kısmında kumpasla yapılan ölçümlerin ortalaması alınarak saptanmıştır. Çap ölçümleri çeliklerin birinci-ikinci göz; beşinci-altıncı göz ve dokuzuncu-onuncu göz arasında yer alan boğumlarda yapılan ölçümlerle saptanmıştır.

Bir yaşlı çelik uzunluğu (cm): Bir yaşlı çeliklerin tek tek metre ile ölçülmesiyle belirlenmiștir.
Bir yaşlı çeliklerde kuru madde oranı (\%): Her uygulamada 4 adet bir yaşlı çelikte kuru madde oranları saptanmıştır. Kuru madde oranları çeliklerin 10. Boğuma kadar her boğum ayrı ayrı saptanmış olup, hem çeliklerin ortalama kuru madde oranları, hem de her yaprak alma seviyesinde çeliklerde boğum sırasına göre kuru madde oranı ayrıca saptanmıștır.

Kuru madde örnekleri kışlık gözlerininde yer aldığı 3-4 gramlık örneklerde saptanmiștır. Her uygulamada 10 boğumlu 4 adet (tekerrür) bir yaşlı dalda (160 örnek) kuru madde oranları belirlenmiştir. Asma gözleri ve sürgün kısmından budama makası ile parçalanan çelik örnekleri tartıldıktan sonra etüvde $105^{\circ} \mathrm{C}$ de ağırlıkları sabit noktaya gelinceye kadar kurumaya bırakılmıștır. Kuru madde oranları aşağıdaki formülle hesaplanmıştır (Cemeroğlu, 2013).

$\%$ Kuru madde $=\frac{\mathrm{M} 3-\mathrm{M} 1}{\mathrm{M} 2-\mathrm{M} 1} \times 100$

M1: Kurutulmuş boş kurutma kabı (g)

M2: İçerisinde deney örneği bulunan kurutma kabının kurutma işlemi öncesi ağırlığı (g)

M3: İçerisinde deney örneği bulunan kurutma kabının kurutma işlemi sonrası ağırlığı (g)

\section{Kış gözlerinde verimliliğin belirlenmesi (salkım sayısı/tomurcuk)}

Uygulamada yer alan Narince çeşidine ait kış gözlerinde verimlilikleri belirlemek amaciyla "Tomurcuk uyanmasını zorlayarak çıkan sürgündeki salkımların saptanması yöntemi" uygulanmıștır (Ağaoğlu, 1970; İlter, 1980). Çalışmada izlenen yol; 6 Mart 2016 tarihinde bağdan alınan çelikler 2 gün oda koşullarında, kaybolan suyun tekrar kazanılması amaciyla da 24 saat daha suda bekletilmiștir. 50 x 25 $\mathrm{cm}$ boyutlarında ve $10 \mathrm{~cm}$ derinliğinde plastik kasanın içerisine ezilmiş mangal kömürü konularak kasanın üzerine $1 \mathrm{~cm}$ x $1 \mathrm{~cm}$ boyutunda delikleri olan ve kasa üstünü kapatacak büyüklükte tel örgü yerleştirilmiştir. Daha sonra tel örgünün üzeri plastik örtü ile kaplanarak her uygulama için 10'ar gözlü 10 çelik (tekerrür) kullanılmıştır. Çeliklerden numaralandırılarak hazırlanan tek gözlü çelikler tesadüf parselleri deneme desenine göre kasa içerisine dikilerek sürdürülmüşlerdir (Taşçı, 2015). Kasalar su ile doldurularak çelik diplerinin su ile temas etmesi sağlanarak kaynaştırma ünitesinde 3 hafta bekletilmiştir (sıcaklık 23-25 ${ }^{\circ} \mathrm{C}$, nem \% 50-65) Her uygulamaya ait göz verimliliği (somak sayısı/göz), uyur haldeki tek gözlü kalemlerin 
(boğum) sürmeye zorlanması ve gözlerin uyanmasından sonra kalemden doğan salkım taslaklarının sayılması yoluyla (salkım sayısı/tomurcuk) tespit edilmiştir. Kasa içerisine odun kömürü konmuş ve iki günde bir kasadaki su değiştirilmiştir.

Her uygulamaya ait 10 sürgün üzerindeki aynı numaralardaki gözlerden elde edilen rakamların ortalaması alınarak; sürmemiş gözler, salkımsız sürgünler ile bir ve iki salkımlı (somaklı) sürgünlerin hangi gözden ne kadar somak verdiği hesaplanmıștır.

\section{Deneme deseni ve verilerin istatistiki analizi}

Denemede 4 uygulama (Kontrol, 2, 4, 6 kez yaprak hasadı) x 3 tekerrür x 10'ar adet asma= 120 adet asma yer almıştır.

Araştırmada elde edilen veriler tesadüf parselleri deneme deseninde faktöriyel yönteme göre varyans analizine tabii tutularak ortalamalar Duncan'a göre gruplandırılmıştır. Çizelgelerde, gruplandırma yapılırken, ortalamalar arasındaki farklılıklar satırda büyük harflerle $(A, B)$, sütunda ise küçük harflerle $(\mathrm{a}, \mathrm{b}, \mathrm{c})$ ifade edilmiştir.

\section{Bulgular ve Tartışma}

Araştırmada yaprak toplama uygulamalarında; 2 dönem hasatta $115 \mathrm{~kg} / \mathrm{da}, 4$ dönem hasatta 186 $\mathrm{kg} / \mathrm{da}$ ve 6 dönem hasatta $215 \mathrm{~kg} / \mathrm{da}$ salamuralık yaprak toplanmıștır. Daha önce bölgede yapılan çalışmalarda 1 dekar bağdan toplanan ortalama taze yaprak miktarını (Cangi ve ark., 2005), 333 kg, (Elmalı, 2008), $400 \mathrm{~kg}$ olarak bildirmișlerdir. $\mathrm{Bu}$ çalışmada asmalardan dönemlere göre toplanan yaprak miktarının normal seviyelerde olduğu görülmüştür.

\section{Yaprak hasadı uygulamalarının çeliklerin gelişimine etkisi}

Araştırmada Narince üzüm çeşidinde, salamuralık yaprak toplama uygulamalarının çelik uzunluğu, çelik ağırlığl, ortalama boğum uzunluğu ve çelik çapına olan etkileri istatistiki açıdan $(\mathrm{p}<0.05)$ önemli farklılıklar çıkmıştır. Bazaldan itibaren ilk 10 boğumda yapılan ölçüm ve tartım sonuçlarına göre, 2,4 ve 6 dönem yaprak toplama uygulamaları çelik ağırlığı, çelik uzunluğu, ortalama boğum uzunluğu ve çelik çapının azalmasına yol açmıştır. Bu açıdan, yaprak hasadı uygulamaları aynı grupta yer alırken kontrol uygulaması daha yüksek çıkmış ve istatistiki olarak farklı grupta yer almıştır (Çizelge 1).

On boğumlu çeliklerde çelik ağırlığı 64.12-44.15 g; çelik uzunluğu 74.89-64.0 cm; ortalama boğum uzunluğu 7.49-6.40 cm; ortalama çelik çapı 8.81-7.71 mm arasında değişmiştir. Çeliklerde yapılan ölçüm sonuçlarına göre, en yüksek değerler kontrol uygulamasında, en düşük değerler ise 6 dönem yaprak toplanan asmalarda saptanmıştır (Çizelge 1; Şekil 1).

Çizelge 1. Narince çeșidinde yaprak hasadı uygulamalarının çelik (10 boğum) gelişimine etkisi

\begin{tabular}{ccccc}
\hline Uygulamalar & $\begin{array}{c}\text { Çelik Ağırlığ } \\
\text { (g/adet)* }\end{array}$ & $\begin{array}{c}\text { Çelik Uzunluğu } \\
(\mathrm{cm})^{*}\end{array}$ & $\begin{array}{c}\text { Ortalama Boğum Uzunluğu } \\
(\mathrm{cm})^{*}\end{array}$ \\
\hline Kontrol & $64.12 \mathrm{a}$ & $74.89 \mathrm{a}$ & $7.49 \mathrm{a}$ \\
2 Hasat & $53.17 \mathrm{~b}$ & $71.00 \mathrm{ab}$ & $7.10 \mathrm{ab}$ & $8.81 \mathrm{a}$ \\
4 Hasat & $47.16 \mathrm{~b}$ & $66.39 \mathrm{~b}$ & $6.64 \mathrm{~b}$ & $8.09 \mathrm{~b}$ \\
6 Hasat & $44.15 \mathrm{~b}$ & $64.00 \mathrm{~b}$ & $6.40 \mathrm{~b}$ & $7.89 \mathrm{~b}$ \\
\hline
\end{tabular}

*Aynı sütunda aynı küçük harfle gösterilen ortalamalar arasında fark $\mathrm{p}<0.05$ seviyesinde önemsizdir.

Kara ve Ağaoğlu (1992), Narince çeşidinde ilk 10 boğumun ortalama çapının anaçlara göre $11.47 \mathrm{~mm}$ (8B) ile $9.92 \mathrm{~mm}(420 \mathrm{~A})$ arasında değiştiğini, $1103 \mathrm{P}$ anacında ise çelik çapının $10.95 \mathrm{~mm}$ olduğunu bildirmişlerdir. Bizim çalışmamızın yapıldı̆̆ı bağda ek sulama yapılmaması ve asmalardan önemli miktarda yaprak toplanması nedeniyle bir yaşlı dal (çelik) çap ve boylarının daha düşük değer vermesi normal görülmüştür.

Yoğun sürgün gelişiminin olduğu erken dönemde yaprak alma, fotosentetik aktivite yüzeyini azaltılması nedeniyle toplam sürgün fotosentez seviyesinde \%70'in üzerinde azalmaya neden olabilmektedir. Fotosentetik şok tüketim yapan organların gelișmesinin durmasına neden olmaktadır (Intrieri ve ark., 2008). Ayrica sert yaprak alma uygulamalarının verim ve gelişmeyi olumsuz yönde etkilediği pek çok kaynakta bildirilmektedir (May ve ark., 1969; Kliewer, 1970; Kliewer ve Ough, 1970; Kliewer ve Fuller, 1973). Yaprak hasat döneminin ve toplanan yaprak miktarının artması ile fotosentez kapasitesinin etkilendiği, omcada vejetatif gelişmenin göstergesi olan bir yaşlı dal gelişiminin olumsuz etkilendiği çalışmamızda açıkça görülmüştür. 


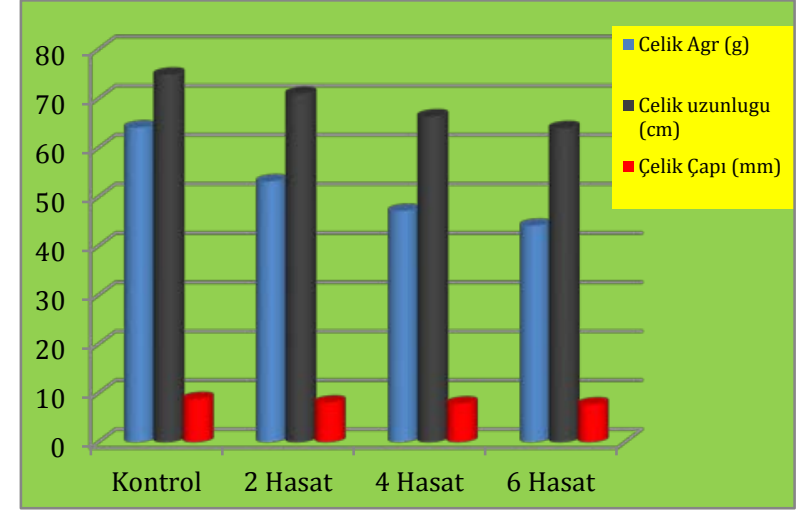

Şekil 1. Narince çeşidinde yaprak hasadı uygulamalarının çelik gelişimine etkisi

\section{Yaprak hasadı uygulamalarının çeliklerin kuru madde oranına etkisi}

Çalışmada, boğumlarda (1-10. boğum arası) saptanan kuru madde oranları Çizelge 2'de sunulmuştur. Çeliklerin ortalama kuru madde oranları ile boğumlardaki kuru madde oranları üzerine yaprak hasadı uygulamalarının etkisi istatistiki açıdan $(\mathrm{p}<0.05)$ önemli farklılıklara neden olmuştur. Çeliklerin ortalama kuru madde oranları 2 dönem yaprak hasadı uygulamasında en yüksek
(\%50.98) 6 dönem hasat uygulamasında en düşük oranda (\%47.93) belirlenmiştir. Boğumlardaki kuru madde oranları uygulamalara göre incelendiğinde, 2 dönem yaprak hasadı uygulaması çeliklerin kuru madde oranının artmasını sağlamış, 4 ve 6 dönem yaprak hasadı uygulamalarının ise çeliklerin kuru madde oranının düşmesine yol açtığı görülmüştür (Çizelge 2).

Boğum pozisyonuna göre kuru madde oranları uygulamalara göre istatistiki açıdan farklılık göstermiștir. Genel olarak ilk 10 boğumda yapılan değerlendirmede, en yüksek kuru madde oranı 2 dönem hasat yapılan örneklerde, en düşük ise 6 dönem hasat yapılan örneklerde saptanmıştır. Ortalama kuru madde oranları ile bazaldan apikale doğru boğum pozisyonları arasında doğrusal bir ilişki saptanmamıştır. Ancak dip gözlerde (1-4 göz) kuru madde oranının daha yüksek olduğu, orta boğumlarda daha düşük ve uç gözlerde tekrar hafif bir yükselme olduğu görülmüştür. Çalışmada kuru maddeler kışlık gözlerin yer aldığı boğum kısımlarının da dâhil edildiği örneklerde belirlenmiş olması bu değişimde etkili olmuştur (Çizelge 2; Şekil 2).

Çizelge 2. Narince çeşidinde yaprak hasadı uygulamalarının boğumların kuru madde oranına etkisi

\begin{tabular}{|c|c|c|c|c|c|}
\hline \multirow{3}{*}{ Boğum No * } & \multicolumn{5}{|c|}{ Uygulamalar } \\
\hline & Kontrol** & 2 Hasat** & 4 Hasat** $^{* *}$ & 6 Hasat** & Ortalama** \\
\hline & \multicolumn{5}{|c|}{ Kuru Madde Oranı (\%) } \\
\hline 1. Göz* & A51.76 a & A52.03b & A50.56 ab & A50.11a & $51.45 \mathrm{a}$ \\
\hline 2. Göz* & B48.41 b & A52.28b & B49.901c & C47.04bc & $50.19 \mathrm{ab}$ \\
\hline 3. Göz* & AB50.5 a & A52.34b & A51.68 ab & B48.45b & $51.50 \mathrm{a}$ \\
\hline 4. Göz* & B48.44 b & B50.20d & A49.10a & B47.80b & $50.03 \mathrm{ab}$ \\
\hline 5. GöZ* & B49.38 ab & A51.62a & $\mathrm{B} 48.78 \mathrm{a}$ & B48.91b & $49,46 \mathrm{ab}$ \\
\hline 6. Göz* & $\mathrm{B} 47.79 \mathrm{~b}$ & $\mathrm{~A} 53.01 \mathrm{ab}$ & $\mathrm{AB} 49.84 \mathrm{~b}$ & $\mathrm{~B} 46.58 \mathrm{bc}$ & $48.54 \mathrm{~b}$ \\
\hline 7. Göz* & $\mathrm{C} 48.29 \mathrm{~b}$ & A52.05a & $\mathrm{B} 50.80 \mathrm{ab}$ & $\mathrm{C} 48.90 \mathrm{~b}$ & $48.99 \mathrm{ab}$ \\
\hline 8. Göz* & $\mathrm{B} 48.40 \mathrm{~b}$ & $\mathrm{~A} 53.22 \mathrm{a}$ & AB51.43 ab & AB49.38ab & $50.01 \mathrm{ab}$ \\
\hline 9. Göz* & $\mathrm{B} 49.23 \mathrm{~b}$ & A51.19b & $\mathrm{B} 49.20 \mathrm{a}$ & BB48.23a & $49.87 \mathrm{ab}$ \\
\hline 10. Göz* & $\mathrm{B} 48.44 \mathrm{~b}$ & $\mathrm{~A} 50.16 \mathrm{c}$ & B $48.75 b$ & $\mathrm{C} 43.89 \mathrm{c}$ & $49.16 \mathrm{ab}$ \\
\hline Ortalama & B49.06 & A50.98 & B49.99 & $\mathrm{C} 47,93$ & \\
\hline
\end{tabular}

*Aynı satırda aynı büyük harfle gösterilen ortalamalar arasında fark $\mathrm{p}<0.05$ seviyesinde önemsizdir.

**Aynı sütunda aynı küçük harfle gösterilen ortalamalar arasında fark p<0.05 seviyesinde önemsizdir.

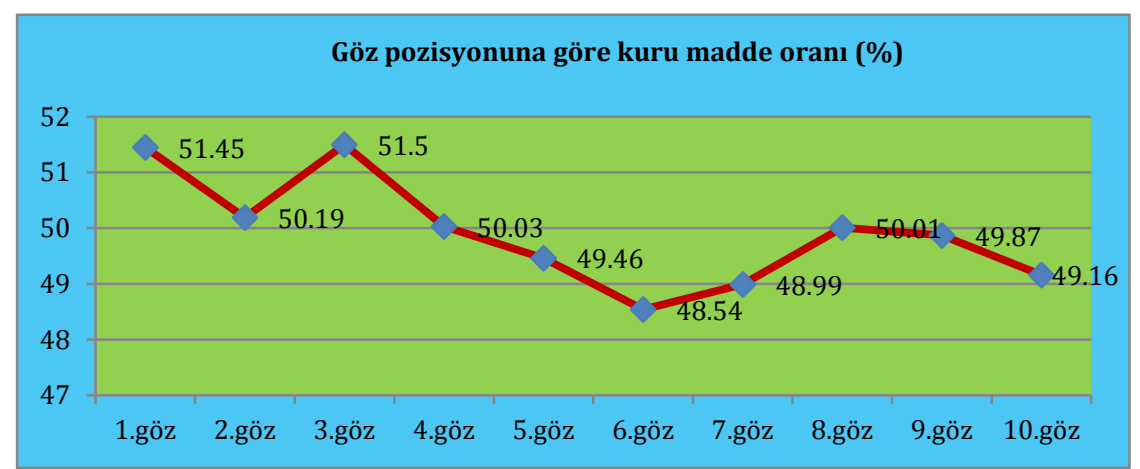

Şekil 2. Narince çeșidinde göz pozisyonuna göre kuru madde oranları 


\section{Yaprak hasadı uygulamalarının göz verimliliğine etkisi}

Yaprak hasat uygulamaları arasında göz verimliliği bakımından istatistiki açıdan fark çıkmış olup, kontrol, 2 ve 4 dönem hasat aynı grupta yer alırken, 6 dönem hasat en düşük değeri vermiştir. 10 boğumun ortalamasına göre, en fazla salkım sayısı 1.215 adet salkım/boğum ile 2 dönem yaprak hasat uygulamasında, en düşük ise 0.97 adet salkım/boğum ile 6 dönem yaprak hasat uygulamasında belirlenmiştir (Çizelge 3). Göz verimliliği açısından boğumlar arasında istatistiki açıdan $\quad(p<0.05)$ önemli farklılıklar olduğu belirlenmiştir. Dip gözlerin genel olarak daha düşük verime sahip olduğu, 5 . ve 6 . gözlerin en verimli gözler olduğu saptanmıştır. Göz seviyesine göre, en düşük ortalama salkım sayısı 1. gözde 0.538 adet salkım/boğum, en yüksek ise 1.475 adet salkım/boğum ile 6. gözde belirlenmiştir (Çizelge 3; Şekil 3).

Çizelge 3. Narince çeşidinde yaprak hasadı uygulamalarının göz verimliliğine etkisi

\begin{tabular}{|c|c|c|c|c|c|}
\hline \multirow{3}{*}{ Boğum No } & \multicolumn{5}{|c|}{ Uygulamalar } \\
\hline & Kontrol* & 2 Hasat* & 4 Hasat* & 6 Hasat* & Ortalama* \\
\hline & \multicolumn{5}{|c|}{ Salkım Sayısı/Boğum } \\
\hline 1. Göz & $0.50 \mathrm{~d}$ & $0.65 \mathrm{e}$ & $0.55 \mathrm{e}$ & $0.45 \mathrm{e}$ & $0.538 \mathrm{~d}$ \\
\hline 2. Göz & $1.10 \mathrm{ab}$ & $1.15 \mathrm{~cd}$ & $0.90 \mathrm{~d}$ & $0.75 \mathrm{~d}$ & $0.975 \mathrm{~cd}$ \\
\hline 3. Göz & $0.95 \mathrm{~cd}$ & $0.95 \mathrm{de}$ & $1.11 \mathrm{~cd}$ & 0.85 cde & $0.965 \mathrm{~cd}$ \\
\hline 4. Göz & $1.30 \mathrm{ab}$ & $1.25 \mathrm{abc}$ & $1.25 \mathrm{bc}$ & $0.95 \mathrm{~cd}$ & $1.188 \mathrm{c}$ \\
\hline 5. Göz & $1.35 \mathrm{a}$ & $1.55 \mathrm{a}$ & $1.45 \mathrm{~b}$ & $1.15 \mathrm{abc}$ & $1.375 \mathrm{ab}$ \\
\hline 6. Göz & $1.40 \mathrm{ab}$ & $1.60 \mathrm{a}$ & $1.65 \mathrm{a}$ & $1.25 \mathrm{a}$ & $1.475 \mathrm{a}$ \\
\hline 7. Göz & $1.15 b c$ & $1.40 \mathrm{ab}$ & $1.30 \mathrm{bc}$ & $1.15 \mathrm{abc}$ & $1.25 \mathrm{~b}$ \\
\hline 8. Göz & $1.25 \mathrm{abc}$ & $1.30 \mathrm{abc}$ & $1.30 \mathrm{bc}$ & $1.20 \mathrm{ab}$ & $1.270 \mathrm{~b}$ \\
\hline 9. Göz & $1.15 b c$ & $1.20 \mathrm{bcd}$ & $1.3 \mathrm{bc}$ & $1.10 \mathrm{bcd}$ & $1.150 \mathrm{c}$ \\
\hline 10. Göz & $1.10 \mathrm{bc}$ & $1.10 \mathrm{~cd}$ & $1.15 \mathrm{~cd}$ & 0.85 cde & $1.038 \mathrm{~cd}$ \\
\hline Ortalama & A 1.175 & $\mathrm{~A} 1.215$ & $\mathrm{~A} 1.176$ & B 0.970 & \\
\hline
\end{tabular}

*Aynı sütunda aynı küçük harfle gösterilen ortalamalar arasında fark p<0.05 seviyesinde önemsizdir.

**Aynı satırda aynı büyük harfle gösterilen ortalamalar arasında fark $\mathrm{p}<0.05$ seviyesinde önemsizdir.

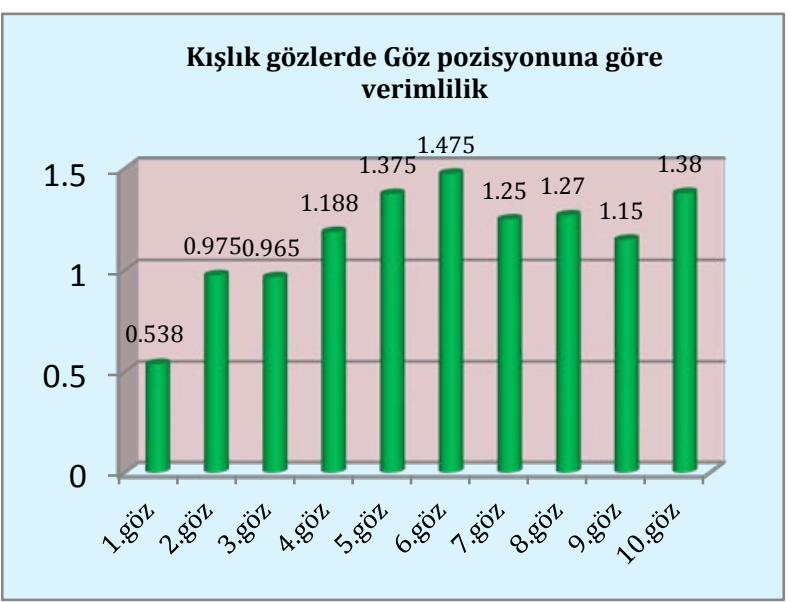

Şekil 3. Narince çeșidinde kışlık gözlerde göz pozisyonuna göre verimlilik durumu

Asmalardan yaprak hasadı uygulamaları kış gözlerinde verimliliği kısmen etkilemiştir. Özellikle 6 dönem hasat uygulamasında göz verimliliği olumsuz yönde etkilenmiștir. 2 ve 4 dönem yaprak toplama kış gözlerinde göz verimliliğine olumlu etki yapmıştır.

Generatif farklılaşma ile sürgün üzerindeki yaprak sayısı, gelişim hızının yüksekliği ve sürgün uzunluğu arasında bir etkileşim olduğu saptanmıştır (Ağaoğlu,
1973; Ağaoğlu, 2002). V. vinifera' larda fizyolojik ve morfolojik ayrım periyodu mayıs ayı içerisinde başlamakta haziran sonu temmuz başlarında tamamlandığı bildirilmektedir (Çelik, 1998; Çelik ve ark., 1998). Bizim çalışmamızda yaprak hasadı çiçeklenme öncesi (mayıs sonu) ile haziran sonu arasında gerçekleştirildiği dikkate alınırsa, morfolojik ve fizyolojik ayrım periyodu döneminde yaprakların toplandığı görülmüștür.

May ve ark. (1969), çiçeklenmeden yaklaşık 4 hafta sonra Sultani asmalarında \%10'dan \%35'e kadar oranda yaprak alma uygulamalarının, tane gelişimini ve takip eden yıldaki göz verimliliğini azalttı̆̆ını, yaprak alma oranı arttıkça bu etkinin daha belirgin bir şekilde gerçekleștiğini bildirmişlerdir.

Çalışmamızda özellikle 6 dönem yaprak toplanan asmalarda bir yıl sonraki göz verimliliğinin en düşük değerde çıkması, daha önce fizyolojik ve morfolojik ayrım periyodu döneminde yaprak alma uygulamalarının olumsuz etkileri ile ilgili bulgularla örtüşmektedir (May ve ark.,1969; Currle ve ark., 1983; Intrieri ve ark., 2008).

Araştırmada hiç yaprak toplanmayan ve asmanın iç kısımları yeterince güneş ışığından yararlanamadığı 
kontrol uygulamasında bir yıl sonra kış gözlerinde verimlilik düşük çıkmıştır. $\mathrm{Bu}$ durum, asmanın gölgelenmesi durumunda kıș gözü verimliliğini çeșit ve gözlerin pozisyona göre \%20-40 azalttığı bulgusu (Ağaoğlu, 1969) ile alakalı olduğu düşünülmektedir.

Dengeli miktarda asmadan yaprak almanın kış gözü verimliliğini olumlu yönde etkilediğinin göstergesi, 2 ve 4 dönem yaprak toplama uygulamaları ile gerçekleştiği görülmüştür.

Çalışmada ortalama göz verimliliği, uygulamalara göre 0.97-1.215 adet / salkım arasında; göz pozisyonuna göre ise 0.538-1.475 adet / salkım arasında değişmiştir. Çalışmada kış gözlerinde verimlilik kontrol ve 6 dönem yaprak toplanan asmalarda 2 ve 4 dönem yaprak toplanan asmalara göre düşük çıkmıştır. Boğum pozisyonu açısından dip gözlerde verim daha düşük çıkmıștır. En yüksek salkım sayısı 5 . ve 6 . boğumdaki gözlerde belirlenmiștir. Salkım sayılarının ilk boğumlarda düşük, orta kısımlarda yüksek ve son kısımlara doğru ise azalma gösterdiği saptanmıștır.

Her gözdeki salkım taslağı sayısı çeşitlere göre farklı olup bu sayı aynı çeşitte, gözlerin bir yaşlı dal üzerinde yer aldığı boğuma göre değişmektedir. Salkım taslaklarının oluşumu üzerine iklim faktörlerinden sıcaklık (Buttrose, 1974a; Ağaoğlu ve Kara, 1990), ışık intensitesi (Ağaoğlu, 1969), gün uzunluğu (Buttrose, 1974a), gölgeleme veya ışık yoğunluğu (Fidan, 1985; Çelik, 2007), sulama (Buttrose, 1974b), gübreleme, boğum pozisyonu ve anaç (Clingeleffer, 1989; Kara ve Ağaoğlu, 1992) ile yetiştirildiği çevre şartları (Fidan, 1985), yıllık dalların odunlaşma düzeyi (Önder ve Dardeniz, 2015) gibi çeşitli faktörlerin birbiriyle kombine halde etkili olduğu rapor edilmektedir.

Asma üzerindeki yıllık dalın orta boğumları, genellikle dip ve uç kısımlara kıyasla daha yüksek bir verimliliğe sahiptir (Ağaoğlu ve Kara, 1993; Dardeniz ve Kısmalı, 2005).

Daha önce Narince çeşidinde göz verimliliği konusunda yapılan çalışmalarda; verimliliğin ilk boğumdan itibaren maksimum değere varıncaya kadar arttığı, sonra tekrar azaldığı bildirilmiştir (Ağaoğlu ve Kara, 1993; Karataş ve Ağaoğlu, 2005). Yine maksimum verimlilik açısından yapılan gruplandırmada, Narince çeşidini II. ve III. grupta (46 ve 7-10. boğum) da yer aldığı bildirilmiştir (Ağaoğlu, 1976; Çelik, 1987; Çelik ve ark., 1988; Ağaoğlu ve Kara, 1993).
Kara ve Ağaoğlu (1992), Narince çeşidinde boğumlarda ortalama salkım sayısını 1.83 adet/boğum $\left(\mathrm{SO}_{4}\right)$ ile 1.34 adet/boğum (5BB) arasında saptamışlardır. 1103P anacında ilk 10 boğumda ortalama salkım sayısını 1.60 adet/boğum, en fazla salkımın ise 6 . boğumda belirlendiğini ileri sürmüşlerdir.

Göz verimliliği ile ilgili bulgularımızda; göz pozisyonlarına göre salkım sayısının değişimi ve en fazla salkım bulunan boğumlar açısından daha önceki çalışmalara benzer şekilde seyrettiği görülmüştür (Çelik, 1987; Çelik ve ark.1988; Kara ve Ağaoğlu 1992; Ağaoğlu ve Kara 1993; Dardeniz ve Kismalı, 2005).

Narince çeşidinde daha önce kış gözlerinde belirlenen göz verimlilik değerleri, bizim çalışmamızdan biraz daha yüksektir. Bu durumun, bizim çalışmamızda yaprak alma uygulamalarının yapılması, göz verimlilik değerlerinin yıl, iklim, anaç, çevre şartları, yıllık dalların odunlaşma düzeyi vb. etmenlerden kaynaklandığı düşünülmektedir (Fidan, 1985; Ağaoğlu ve Kara, 1990; Önder ve Dardeniz, 2015).

\section{Sonuç ve Öneriler}

$\mathrm{Bu}$ çalışmada, Narince üzüm çeşidinde farklı miktarda yemeklik asma yaprak toplamanın, yıllık dal gelișimi ve göz verimliliğine etkisi araștırılmıştır. Çalışmada ilk yıl asmalardan 0, 2, 4 ve 6 dönem salamuralık yapraklar toplanmıştır. İkinci yıl ise 10 boğumlu sürgünlerde (çelik) gerekli veriler alınmıştır. Çeliklerde ağırlık, boy, çap ve kuru madde oranları belirlenmiştir. Her uygulamada göz sürdürme metodu ile 10 boğumda ayrı ayrı göz verimlilikleri saptanmıștır.

Asmalardan yoğun miktarda yaprak toplamak yıllık dalın ağırlık, boy ve çap gelişimini olumsuz yönde etkilemiştir. $\mathrm{Bu}$ etki $\% 5$ seviyesinde önemli bulunmuştur.

Aşırı yaprak toplama ve hiç yaprak almama uygulamaları yıllık dalların kuru madde oranını olumsuz yönde etkilemiş, bu etki \%5 seviyesinde önemli bulunmuştur. Bu durum kontrol ve en fazla yaprak toplanan uygulamalarda daha belirgin bir şekilde görülmüştür. Kuru madde oranının ilk boğumlarda yüksek orta kısımlarda ise daha düşük olduğu saptanmıştır.

Yaprak toplama uygulamaları kışlık gözlerde verimliliğe etkisi $(\mathrm{p}<0.05)$ önemli bulunmuştur. Kışlık gözlerde salkım sayısı/boğum en fazla iki dönem yaprak toplanan asmalarda, en az 6 dönem 
yaprak toplanan asmalardan alınan çeliklerde belirlenmiștir. Asmalarda kıșlık göz verimliliği için omcalarda dengeli bir şekilde yaprak toplamanın olumlu etki gösterdiği belirlenmiștir.

Narince çeşidinde kışlık gözlerin göz pozisyonlarındaki genel özelliği olan, ilk boğumlarda düşük, daha sonra artan ve son kısımlarda azalan göz verimlilik durumu bu çalışmada da benzer şekilde saptanmıștır. En yüksek göz verimliliği 5. ve 6 . boğumlardaki gözlerde saptanmıștır.

Sonuç olarak, asmalardan yemeklik amaçla fazla yaprak toplamanın yıllık dal gelişimini olumsuz etkilediği ve göz verimliliğini düşürdüğü açıkça görülmektedir. Asmalardan 2-3 defa dengeli bir şekilde salamuralık yaprak toplanması durumunda, vejetatif ve generatif gelişmede dengenin kurulabileceği söylenebilir.

Tokat yöresinin en önemli üzüm çeşidi olan Narince, üzüm yetiştiriciliği için orta uzunlukta budamaya uygun olmasına rağmen, salamuralık yaprak üretiminin ön planda olması nedeniyle asmalar kısa budanmaktadır. Üreticilerin sadece üzüm yetiştiriciliğine yönelik bağcılık yapacakları zaman, yüksek verim ve kaliteli ürün için yaz budamasını ihmal etmemeleri, en fazla 3-4 dönem yaprak toplamalarının uygun olacağı kanaatine varılmıştır.

\section{Çıkar çatışması}

Yazarlar arasında herhangi bir çıkar çatışması yoktur.

\section{Yazarların katkı beyanı}

A.Ö.: Yüksek lisans öğrencisi, verilerin alınması, analizler ve tezin yazılmasında, R.C.: Tez danışmanı, denemeyi planlama makale yazımında katkı sağlamıştır. T.U.: Araştırmanın ilk yıl asmaların budanması, yaprak alma aşamalarında katkı sağlamıștır.

\section{Kaynaklar}

Ağaoğlu, Y.S., 1999. Bilimsel ve uygulamalı bağcılık (asma biyolojisi) Ankara Üniversitesi Ziraat Fakültesi. Kavaklıdere Eğitim Yayınları No:1. 205 s.

Ağaoğlu, Y.S., 2002. Bilimsel ve uygulamalı bağcllık (Asma Fizyolojisi) Kavaklıdere Eğitim Yayınları, No: 5.

Ağaoğlu, Y.S., 1969. Sofralık üzüm çeşitlerinden Hasandede, Kalecik Karası, Papaz Karası, Öküzgözü ve Furmint'in tomurcuk yapıları, floral gelişme devreleri ve bu çeşitlere uygun budama metotlarının tespiti üzerinde mukayeseli araştırmalar. Ankara Üniversitesi Ziraat Fakültesi, 297 S. (Doktora Tezi).
Ağaoğlu, Y.S., 1970. Asma tomurcuklarının verim potansiyelinin tahmini. Ziraat ve Yayım, 1:12-15.

Ağaoğlu, Y.S., 1973. Asmaların kışlık gözlerinin verimliliği üzerinde bir araştırma. Yalova Bahçe Kült. Araş. Eğt. Merkezi Dergisi 6 (1-2): 47-56.

Ağaoğlu, Y.S., Kara, Z., 1990. Tokat tarımında bağcıllı̆ın yeri ve üzüm çeşitlerinin yöredeki dağılımı üzerinde bir araştırma. Cumhuriyet Üniversitesi Tokat Ziraat Fakültesi Dergisi, 6(1): 293-306.

Ağaoğlu, Y.S., Kara, Z., 1993. Tokat yöresinde yetiştirilen bazı üzüm çeşitlerinin göz verimliliklerinin belirlenmesi üzerinde araştırmalar. Doğa Turkish Journal of Agricultural and Forestry. 17: 451-458.

Ağaoğlu, Y.S.,1976. Asmalarda tomurcuk verimliliğine etki eden faktörler ve verim potansiyelinin önceden tahmini. Ziraat Mühendisliği Sayı: 120: 9-13, 1976.

Alleweldt, G., 1964. Die Umweltabhaengigkeit des vegatativen wachstumsruhe und der blütenbildung von reben (Vitis species). Vitis 4, 240-261.

Alleweldt, G., İlter, E., 1969. Untersuchungen uber die beziehungen zwischen blütenbildung; und triebwachstum bei Reben. Vitis 8. 286-313.

Bekar, T., Cangi, R., 2015. Narince üzüm çeşidinde yaprak hasadının üzüm verimi ve meyve kalitesine etkisi, VII. Ulusal Bahçe Bit Kon, 25-29 Ağus. Çanakkale.

Beslic, Z., Todic, S., Matijasevic, S., 2013. Effect of timing of basal leaf removal on yield components and grape quality ofgrapevine cultivars Cabernet Sauvignon and prokupac ( $V$. vinifera l.). Bulgarian Journal of Agricultural Science, 19(1),96-102.

Buttrose, M.S.,1974a. Climatic Factors and Fruitfulness in Grapevines. Hortic Abstracts, 44 (6),319-325.

Buttrose, M.S.,1974b. Fruitfulness in Grape-Vines: Effect of Water Stress. Vitis 12, 299-305.

Cangi, R., Kaya, C., Kılıç, D., Yıldız, M., 2005. Tokat yöresinde salamuralık asma yaprak üretimi, hasad ve işlemede karşılașilan sorunlar ve çözüm önerileri, 6. Ulusal Bağ. Sempozyumu, Bildiri Kitabı Tekirdağ, 19-23 Eylül 2005.

Cangi, R., Yağcı, A., 2012. Iğdır Yöresinde Salamuralık Asma Yaprağı Üretim İmkanları. Iğdır Üniversitesi Fen Bilimleri Enstitüsü Dergisi, 2(2 Sp: A), 9-14.

Cemeroğlu, B.S., 2013. Gıda Analizleri. Bizim Grup Basımevi, Ankara, $480 \mathrm{~s}$.

Clingeleffer, P.R., 1989. Effect of varrying node number per bearer onyield and juice composition of Cabernet Sauvignon grapevines. AustralianJournal of Experimental Agriculture, 29, 701-705. 
Coombe, B.G., 1959. Fruit set and development in seeded grape varieties as affected by defoliation, topping, girdling, and other treatments, Am. J. Enol. Vitic 1959 vol. 10 no. 2 85-100.

Coombe, B.G., 1962.The Effect of removing leaves, flowers and shoot tips on fruit-set in Vitis vinifera L. J. hort. Sci. 37, 1-15.

Currle, O., Bauer, O., Hofacker, W., Schumann, F., Frish, W., 1983. Biologie der Rebe, D. Meininger Verlag und Druckerei GmbH, 6730, Neustadt.

Çelik, H., 2007. Üzüm Çeşit Kataloğu. Sunfidan A.Ş. Mesleki Kitaplar Serisi: 3. 165 s. Ankara.

Çelik, H., Ağaoğlu, Y.S., Fidan, Y., Marasalı, B., Söylemezoğlu, 1998. Genel Bağcılık. Sunfidan A.Ş. Mesleki Kitaplar Serisi: 1, 253 S. Ankara.

Çelik, H., Marasalı, B., Demir, I., 1988. Ankara koşullarında yetiştirilen bazı şaraplık üzüm çeşitlerinin farklı boğumlarındaki kışlık gözlerin verimlilik düzeylerinin belirlenmesi üzerinde bir araştırma. Türkiye III. Bağcılık Simpozyumu Bildir Özetleri 31Mayıs - 3 Haziran, Bursa, Sayfa No: 15.

Çelik, S., 1998. Bağcıllk (Ampeloloji). Trakya Üniversitesi Ziraat Fakültesi, Bahçe Bitkileri Bölümü. $425 \mathrm{~s}$. Tekirdağ.

Çelik, S.,1987. Yapıncak üzüm çeşidinde kışlık gözlerin verimliliği üzerine sürgün üzerindeki pozisyonlarının etkisi. Doğa 11(3): 550-557.

Dardeniz A., Kısmalı, İ., 2005. Bazı sofralık üzüm çeşitlerinde kış gözü verimliliğinin saptanması ile optimum budama seviyelerinin tespiti üzerine araștırmalar. Ege Üniv., Zir. Fak. Der., Bornova \İzmir, 42(2): 1-10.

Elmalı, Ö., 2008. Tokat ili merkez ilçede bağcllıkla uğraşan işletmelerin üretim ve pazarlama sorunları, GOÜ. Fen Bil. Ens. Yük. Lis. Tez, 152 s., 51.

Fidan, Y., 1966. Sofralık üzüm çeşitlerinden Hafızali, Hamburg Misketi, Çavuş, Balbal ve Razakı'nın tomurcuk yapıları ile mahsuldarlık durumları üzerinde araştırmalar. Tarım Bakanlığı Ziraat İşleri Genel Müdürlügü Neşriyatı D-112, Ankara.

Fidan, Y.,1985. Özel Bağcllık. Ankara Üniv. Ziraat Fak. Yayınları: 930 Ders Kitabi No:265, $401 \mathrm{s.}$

Intrieri C., Filippetti I., Allegro G., Centinari M. ve Poni S., 2008. Early defoliation (hand vs mechanical) for improved crop control and grape composition in Sangiovese (V. vinifera L.). Aust. J. Grape Wine Res., 14 (1), 25-32.
İlter, E., 1980. Yapraklara uygulanan bazı kimyasal maddelerin asmalarda kış gözü verimliliğine etkisi üzerinde araştırmalar. E.Ü. Ziraat Fak. Yayınları No: 372, s 132.

Kara, Z., Ağaoğlu, Y.A., 1992. Farklı amerikan asma anaçlarına aşılanmış Narince üzüm çeşidinde boğumların pozisyonları ve çaplarına göre verim potansiyelinin değișimi üzerinde bir araștırma, I. Ulusal Bahçe Bit Kong İzmir 13-16 Ekim. 587591.

Karataș, H., Ağaoğlu, Y.S., 2005. Fruitfullness in grapevines, Alatarım, 4(1): 13-22.

Kılıç, D. 2007. Narince üzüm çeşidinde farklı budama seviyesi ve azot dozlarının salamuralık asma yaprak verimi ve kalitesi üzerine etkileri. GOÜ. Fen Bil. Ens. Yük. Lis. Tez.

Kliewer, W. M. (1970). Effect of time and severity of defoliation on growth and composition of'Thompson Seedless' grapes. Am.J. of Enol. and Vitic., 21(1), 37-47.

Kliewer, W., Ough, C., 1970. The effect of leaf area and crop level on the concentration of amino, acids and total nitrogen in 'Thompson Seedless' grapes. Vitis 9, 196-206.

Kliewer, W., Fuller, R., 1973. Effect of time and severity of defoliation on growth of roots, trunk, and shoots of Thompson Seedless Grapevines. Am. J. Enol. Vitic. 24, 59-64.

May, P., Shaulis, N.J., Antcliff, A.J., 1969. The effect of controlled defoliation the Sultana vine. Amr. Jour. Enol. Vitic. 20:237-250.

Oraman, M.N., 1959. Yeni Bağcılık. Ankara Üniversitesi Ziraat Fakültesi Yayınları 78. A.Ü. Basımevi. s 298.

Önder, M., Dardeniz, A., 2015. Bazı sofralık üzüm çeşitlerinde yıllık dalların odunlaşma düzeyi ile göz verimliliği arasındaki ilişkilerin belirlenmesi. 8. Bağcılık Sem. Selçuk Tarım ve Gıda Bilimleri Dergisi-A, 27, 98-107.

Poni S., Casalini L., Bernizzoni F., Civardi S., Intrieri C., 2006. Effects of early defoliation on shoot photosynthesis, yield components and grape quality. Am. J. Enol. Vitic., 57, 397- 407.

Taşçı, F., 2015. Bazı Sofralık Üzüm Çeşitlerinde (Vitis vinifera L.) Göz verimliliklerinin ve optimum budama seviyelerinin belirlenmesi", Yüksek Lisans Tezi, GOÜ. Fen Bil. Ens. Tokat.

Winkler, A. J., Cook , J. A., Kliewer , W. M. ve Lider, L.A., 1974. General Viticulture. 633 California. Pres, Berkeley. 